\title{
First-dose and steady-state pharmacokinetics of orally administered crizotinib in children with solid tumors: a report on ADVL0912 from the Children's Oncology Group Phase 1/Pilot Consortium
}

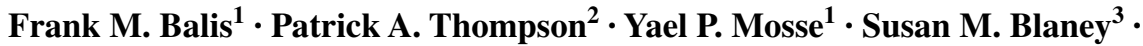 \\ Charles G. Minard ${ }^{3} \cdot$ Brenda J. Weigel $^{4,5} \cdot$ Elizabeth Fox $^{1}$
}

Received: 2 December 2016 / Accepted: 8 December 2016 / Published online: 28 December 2016

(C) The Author(s) 2016. This article is published with open access at Springerlink.com

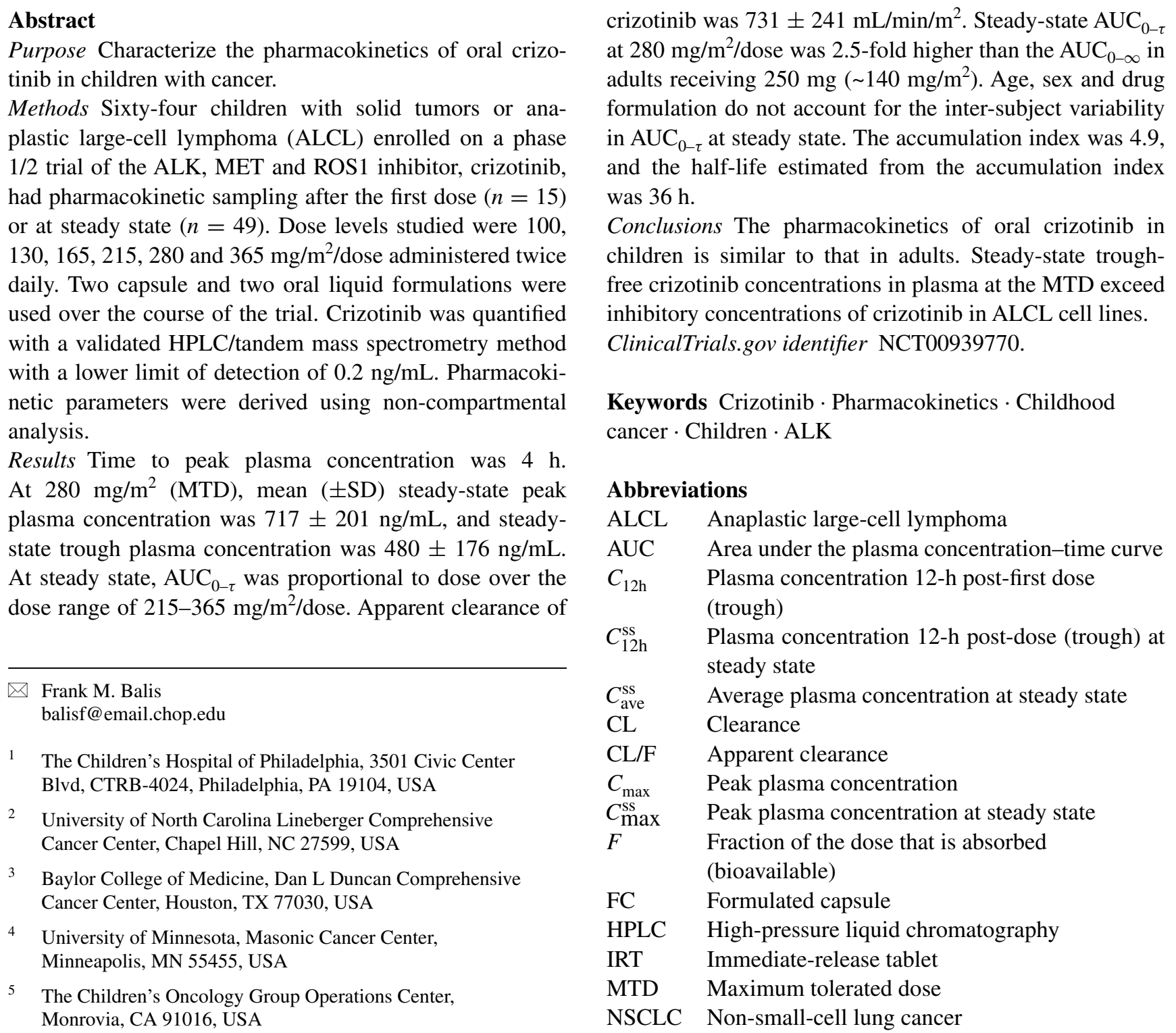




$\begin{array}{ll}\text { OS } & \text { Oral solution } \\ \text { PIB } & \text { Powder in bottle } \\ \text { PIC } & \text { Powder in capsule } \\ R & \text { Accumulation index } \\ \tau & \text { Dosing interval } \\ T_{1 / 2} & \text { Half-life } \\ t_{\text {last }} & \text { Time of last measured plasma concentration } \\ T_{\max } & \text { Time post-dose that the } C_{\max } \text { is reached }\end{array}$

\section{Introduction}

Crizotinib is a small molecule inhibitor of multiple tyrosine kinases, including the anaplastic lymphoma kinase encoded by the $A L K$ gene, hepatocyte growth factor receptor (c-met) encoded by $M E T$ and the tyrosine kinase, ROS encoded by ROS1 [1]. Crizotinib is approved worldwide for the treatment of the subset of non-small-cell lung cancers (NSCLC) with rearrangements involving $A L K$ [2-4]. Responses to crizotinib have also been reported in patients with anaplastic large-cell lymphoma (ALCL) and inflammatory myofibroblastic tumors $[5,6]$, both of which have a high incidence of $A L K$ rearrangements, especially in children [7].

The adult recommended oral dose of crizotinib is $250 \mathrm{mg}$ twice daily, which is equivalent to approximately $140 \mathrm{mg} /$ $\mathrm{m}^{2} /$ dose. The pharmacokinetics of crizotinib in adults has been studied after a single dose and at steady state ( $\geq 15$ days) in patients with NSCLC using 250-mg formulated capsules and after a single $50-\mathrm{mg}$ dose of an experimental intravenous formulation or a single 250-mg dose of three oral formulations [formulated capsules (FC), powder in capsules (PIC) and immediate-release tablets (IRT)] in healthy volunteers $[8,9]$. The mean (C.V.) clearance (CL) of crizotinib was $47(18 \%) \mathrm{L} / \mathrm{h}$, the volume of distribution at steady state was $1770(18 \%) \mathrm{L}$ and the half-life $\left(T_{1 / 2}\right)$ was 39 $(16 \%) \mathrm{h}$, following the intravenous dose. The absolute bioavailability $(F)$ of the IRT formulation was $43 \%$. After oral administration, the time to peak concentration $\left(T_{\max }\right)$ was $5 \mathrm{~h}$, the peak plasma concentration $\left(C_{\max }\right)$ was $120-135 \mathrm{ng} /$ $\mathrm{mL}$, and the area under the plasma concentration-time curve extrapolated to infinity $\left(\mathrm{AUC}_{0-\infty}\right.$ ) was $2700-2900 \mathrm{ng} \mathrm{h} / \mathrm{mL}$. The three oral formulations were bioequivalent. The accumulation index $(R)$ at steady state was 4.5 .

A separate phase $1 / 2$ trial of oral crizotinib administered twice daily using PIC, FC and two liquid formulations was conducted in children with solid tumors and ALCL [6]. Dose levels studied were 100, 130, 165, 215, 280 and $365 \mathrm{mg} / \mathrm{m}^{2} /$ dose, and the maximum tolerated dose (MTD) was $280 \mathrm{mg} / \mathrm{m}^{2} /$ dose, which is twofold higher than the adult recommended dose. Steady-state pharmacokinetic parameters in 18 children receiving $280 \mathrm{mg} / \mathrm{m}^{2} / \mathrm{dose}$ were briefly summarized in the previously reported phase $1 / 2$ trial results [6]. This report describes in more detail the pharmacokinetics of crizotinib in children enrolled on the phase $1 / 2$ trial and includes 64 subjects treated at the six dose levels and studied after the first dose $(n=15)$ or at steady state $(n=49)$. The previously reported 18 patients are included in this cohort.

\section{Materials and methods}

\section{Drug}

Crizotinib was provided by Pfizer Inc. (New York, NY) in four formulations over the course of the phase $1 / 2$ clinical trial:

- PIC in 10, 50 and $100 \mathrm{mg}$ strengths,

- FC (commercial formulation) in 150, 200 and $250 \mathrm{mg}$ strengths,

- Powder in bottles (PIB) containing $2500 \mathrm{mg}$ in a $4 \mathrm{oz}$ vial that is reconstituted to a $25 \mathrm{mg} / \mathrm{mL}$ suspension,

- Oral solution (OS) containing $25 \mathrm{mg} / \mathrm{mL}$ in a sweetened and flavored aqueous vehicle. OS replaced PIB.

The OS is bioequivalent to FC in adults (Pfizer, data on file).

\section{Study design}

The pediatric phase $1 / 2$ trial of crizotinib (ADVL0912) was sponsored by Pfizer Inc. and conducted within the twentyone member institutions of the Pediatric Phase 1 and Pilot Consortium plus five additional sites. The protocol was conducted in accordance with the Declaration of Helsinki and approved by the Institutional Review Boards at all participating institutions. Informed consent was obtained from all subjects who were 18 years or older or from the parents of subjects under the age of 18 years. The eligibility criteria, trial design and subject cohorts have been previously reported [6]. Crizotinib was administered orally, twice daily, continuously at doses of 100, 130, 165, 215, 280 and $365 \mathrm{mg} / \mathrm{m}^{2} /$ dose on the phase 1 dose escalation portion of the trial and at a dose of $280 \mathrm{mg} / \mathrm{m}^{2} /$ dose after this dose was identified as the MTD. For this report, the administered dose per $\mathrm{m}^{2}$ was calculated by dividing the patient's dose (in $\mathrm{mg}$ ) that was determined by a dosing nomogram in the protocol by their body surface area. In subjects receiving capsules, the administered dose per $\mathrm{m}^{2}$ often deviated slightly from the dose level because of dosing limitations imposed by capsule size.

\section{Sample collection and processing}

Subjects studied after their first dose of crizotinib had $2 \mathrm{~mL}$ blood samples collected into potassium EDTA-containing tubes prior to the dose and $0.5,1,2,4,6,8$ and $24 \mathrm{~h}$ after 
the morning dose. The evening dose of crizotinib was not administered on day 1 in these subjects. A trough blood sample was also drawn prior to the morning dose on day 7 . Subjects studied at steady state (day 15-28 of cycle 1) had blood samples drawn prior to their first dose on day 1, prior to the morning dose at steady state and then $1,2,4,6-8 \mathrm{~h}$ after the morning dose. Blood samples were protected from light and placed on ice. Plasma was separated by centrifugation at $1700 \mathrm{~g}$ for $10 \mathrm{~min}$ at $4{ }^{\circ} \mathrm{C}$ and immediately frozen at -20 to $-70{ }^{\circ} \mathrm{C}$ until assayed.

\section{Crizotinib assay}

Plasma concentrations of crizotinib were quantified by Covance Bioanalytical Services (Indianapolis, IN) using a previously described, validated high-pressure liquid chromatography (HPLC), tandem mass spectroscopic method with a lower limit of quantification of $0.2 \mathrm{ng} / \mathrm{mL}$ [8].

\section{Pharmacokinetic analysis}

Crizotinib plasma concentration-time data were analyzed using model-independent methods. The area under the crizotinib plasma concentration-time curve to the last measured time point $\left(\mathrm{AUC}_{0-\text { tlast }}\right)$ was derived using the linear trapezoidal rule. The limited sampling duration did not allow for accurate estimation of the terminal slope of the plasma concentration-time curve after the first dose. As a result, the terminal $T_{1 / 2}$ could not derived, and the AUC could not be accurately extrapolated to infinity $\left(\mathrm{AUC}_{0-\infty}\right)$ in the subjects studied after the first dose. For calculating the steady-state AUC over the 12-h dosing interval $(\tau)$, which is equivalent to $\mathrm{AUC}_{0-\infty}$ after a single dose, the trough concentration drawn prior to the dose was also used as the 12-h post-dose concentration. The average plasma crizotinib concentration at steady state $\left(C_{\mathrm{ave}}^{\mathrm{ss}}\right)$ was derived by dividing the $\mathrm{AUC}_{0-\tau}$ by $\tau(12 \mathrm{~h})$, and the apparent clearance $(\mathrm{CL} / \mathrm{F})$ of crizotinib is the dose divided by $\mathrm{AUC}_{0-\tau}$.

$R$ was derived by dividing the day 7 steady-state trough concentration $\left(C_{12 \mathrm{~h}}^{\mathrm{ss}}\right)$ by the concentration $12 \mathrm{~h}$ after the first dose $\left(\mathrm{C}_{12 \mathrm{~h}}\right) . \mathrm{C}_{12 \mathrm{~h}}$ was estimated by extrapolation using the slope estimated from the $\mathrm{Ln}$ transformed 8 and $24 \mathrm{~h}$ plasma concentrations. $T_{1 / 2}$ was estimated from the mean $R$ by rearranging the equation for calculating $R$ from the $T_{1 / 2}$ :

$$
R=\frac{1}{\left[1-\mathrm{e}^{\left(-\frac{0.693}{t_{1} / 2} \cdot \tau\right)}\right]} .
$$

\section{Statistical analysis}

A linear multiple regression model was used to assess the relationship between $\mathrm{AUC}_{0-\tau}$ normalized to the administered dose $/ \mathrm{m}^{2}$ at steady state and age, gender and drug formulation using the $l m$ function in R statistical software package (The R Foundation for Statistical Computing, http://www.R-project.org).

\section{Results}

\section{Subjects}

Seventy-five subjects had pharmacokinetic blood samples drawn after their first dose of crizotinib $(n=15)$ or at steady state immediately prior to and after their morning dose $(n=60)$. The data from 11 subjects studied at steady state were not evaluable because the trough sample was not drawn at the appropriate time $(n=6)$, samples were missed $(n=2)$, the dose of crizotinib had been reduced for prior toxicity $(n=1)$, the dose was spit out $(n=1)$, or the preceding evening dose had not been given $(n=1)$. The characteristics of the 64 subjects with evaluable data are listed in Table 1.

\section{First-dose pharmacokinetics}

Figure 1 shows the mean plasma crizotinib concentration-time profiles for subjects studied after the first dose at four dose levels, and Table 2 provides the pharmacokinetic parameters. Figure 2 shows the relationship of dose to $\mathrm{AUC}_{0 \text {-tlast }} \cdot \mathrm{AUC}_{0 \text {-tlast }}$ does not appear to increase in proportion to the dose over the twofold dose range (100$215 \mathrm{mg} / \mathrm{m}^{2}$ ). This may reflect the substantial inter-subject

Table 1 Subject characteristics

\begin{tabular}{lll}
\hline & First dose & Steady state \\
\hline Number & 15 & 49 \\
Median (range) age (year) & $11.9(5.7-21.4)$ & $10.1(2.6-22)$ \\
Male/female & $10: 5$ & $23: 26$ \\
Dose level (mg/m $/$ dose) & & \\
100 & 3 & \\
130 & 3 & 1 \\
165 & 7 & 5 \\
215 & 2 & 36 \\
280 & & 7 \\
365 & & \\
Formulation & & $28^{\mathrm{a}}$ \\
Powder in capsule & 14 & 8 \\
Powder in bottle & 1 & 9 \\
Formulated capsule & & 4 \\
Oral solution & & \\
\hline
\end{tabular}

a One subject received a combination of powder in capsule and powder in bottle 

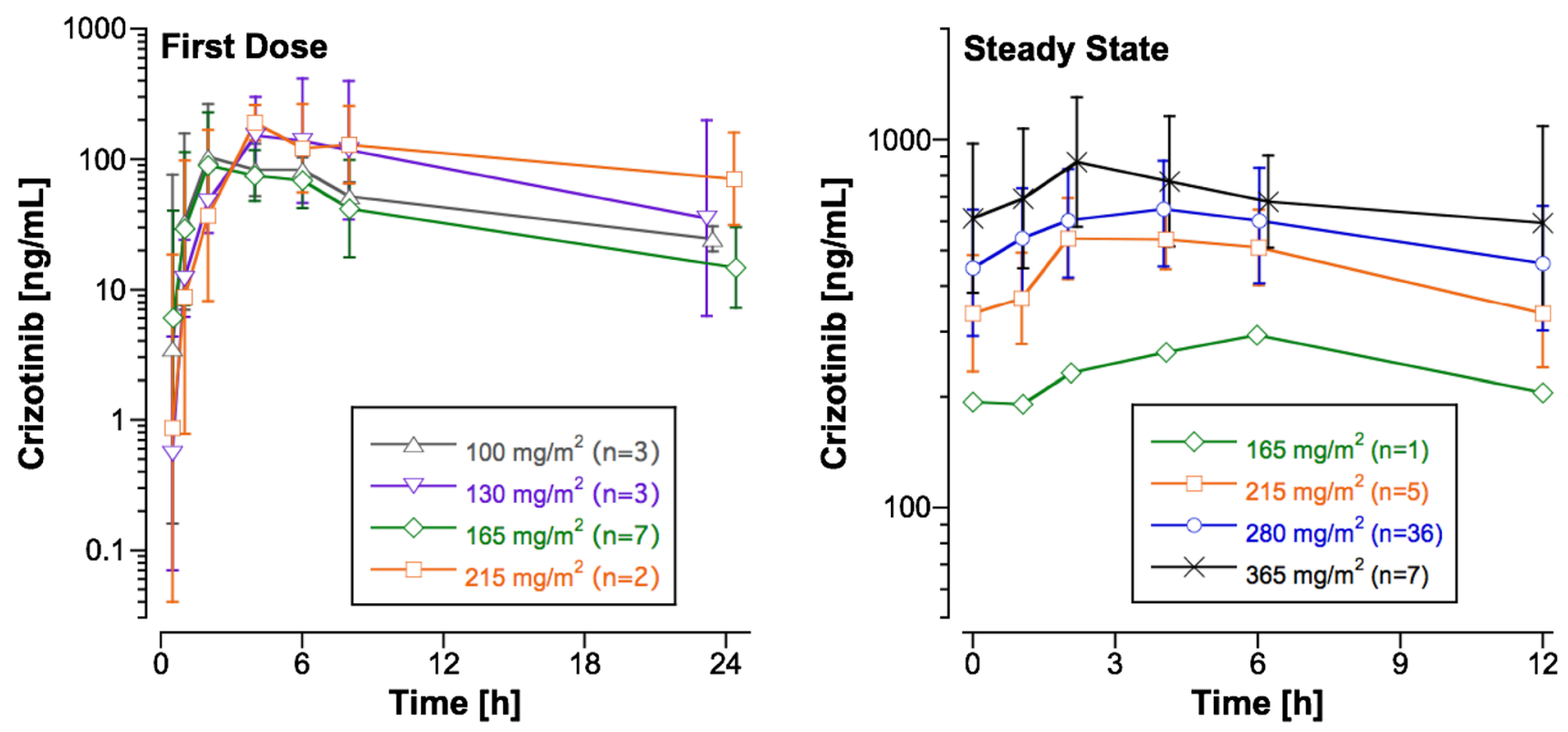

Fig. 1 Plasma concentration-time profiles in subjects studied after the first dose and at steady state at 6 dose levels. Points are the geometric mean and error bars are the SD

Table 2 Pharmacokinetic parameters for oral crizotinib studied after the first dose in children with solid tumors or ALCL at four dose levels ranging from 100 to $215 \mathrm{mg} / \mathrm{m}^{2} /$ dose

\begin{tabular}{llllll}
\hline Dose level $\left(\mathrm{mg} / \mathrm{m}^{2} /\right.$ dose $)$ & Number of subjects & $C_{\max }(\mathrm{ng} / \mathrm{mL})$ & $T_{\max }(\mathrm{h})$ & $\mathrm{AUC}_{0-\text { tlast }}(\mathrm{ng} \mathrm{h} / \mathrm{mL})$ & $R$ \\
\hline 100 & 3 & $144 \pm 97$ & $3.3 \pm 2.2$ & $1260 \pm 320$ & $2.8 \pm 1.6$ \\
130 & 3 & $236 \pm 217$ & $4.7 \pm 1.1$ & $3300 \pm 3913$ & $5.8 \pm 2.9$ \\
165 & 7 & $145 \pm 70$ & $3.7 \pm 2.4$ & $1208 \pm 558$ & $5.2 \pm 2.1$ \\
215 & 2 & $196 \pm 60$ & $4.0 \pm 0$ & $2820 \pm 1890$ & $5.0 \pm 2.3$ \\
\hline
\end{tabular}

Fourteen of the 15 subjects received the PIC formulation. Values represent the mean \pm SD

variability (C.V. for the $\mathrm{AUC}_{0-\mathrm{tlast}}$ normalized to the administered dose per $\mathrm{m}^{2}$ was $105 \%$ ), as well as the small cohort size and the influence of an outlier at $130 \mathrm{mg} / \mathrm{m}^{2} / \mathrm{dose}$ (Fig. 2). The mean $R$ across the four dose levels was 4.9 , and the $T_{1 / 2}$ of crizotinib estimated from the mean $R$ was $36 \mathrm{~h}$.

\section{Steady-state pharmacokinetics}

The crizotinib plasma concentration-time profile over the 12-h dosing interval at steady state for the dose levels ranging from 165 to $365 \mathrm{mg} / \mathrm{m}^{2}$ is shown in Fig. 1, and the mean $( \pm \mathrm{SD})$ steady-state pharmacokinetic parameters are listed in Table 3. At steady state, the increase in $\mathrm{AUC}_{0-\tau}$ is dose-proportional over the narrow dose range (215 to $365 \mathrm{mg} / \mathrm{m}^{2}$ ). The variability appears to be lower at steady state (C.V. for the $\mathrm{AUC}_{0-\tau}$ normalized to the administered dose per $\mathrm{m}^{2}$ was $30 \%$ ) than after the first dose. The mean $( \pm \mathrm{SD}) \mathrm{CL} / \mathrm{F}$ of crizotinib after oral dosing in children was
$731 \pm 241 \mathrm{~mL} / \mathrm{min} / \mathrm{m}^{2}$. The ratio of the steady-state peak plasma concentration $\left(C_{\mathrm{max}}^{\mathrm{ss}}\right)$ to $C_{12 \mathrm{~h}}^{\mathrm{ss}}$ at the $280 \mathrm{mg} / \mathrm{m}^{2}$ dose level $(n=36)$ was $1.6 \pm 0.5$, which reflects the intrasubject variation in plasma crizotinib concentrations over the dosing interval at steady state.

A multiple regression analysis evaluating the impact of age, gender and drug formulation on the $\mathrm{AUC}_{0-\tau}$ normalized to the administered dose per $\mathrm{m}^{2}$ at steady state in 49 subjects demonstrated that these characteristics did not account for the variability in $\mathrm{AUC}_{0-\tau}$ (multiple $R^{2}=0.11$; $p=0.40$ ). Figure 3 shows the relationship between the normalized $\mathrm{AUC}_{0-\tau}$ and age, gender and drug formulation.

\section{Discussion}

We characterized the pharmacokinetics of orally administered crizotinib in children after the first dose and at steady state ( $\geq 14$ days of continuous twice daily dosing), at 6 

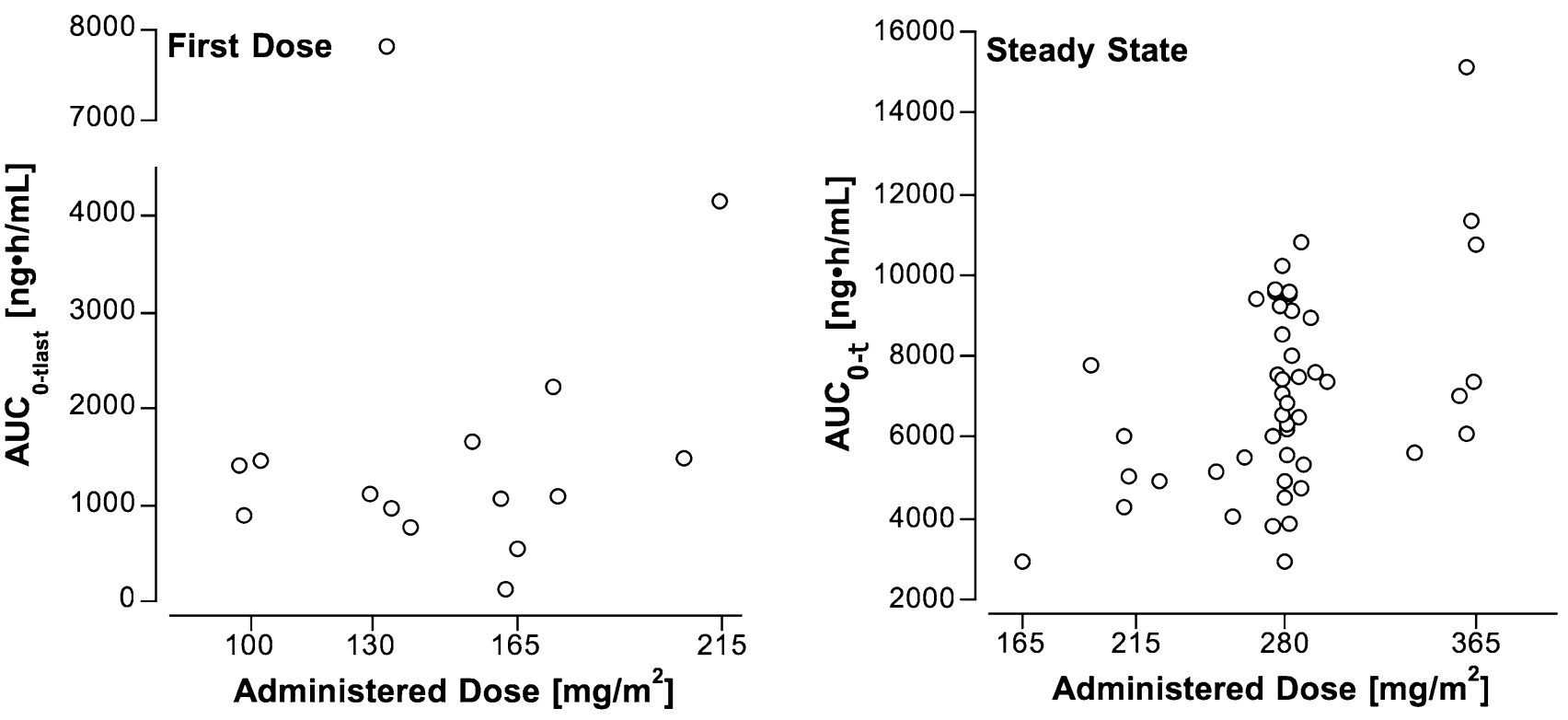

Fig. 2 Relationship between AUC to the last measured time point ( $24 \mathrm{~h})$ for subjects studied after the first dose or AUC over the 12-h dosing interval at steady state and the administered dose of oral crizotinib normalized to subject's body surface area

Table 3 Pharmacokinetic parameters for oral crizotinib studied at steady state in children with solid tumors or ALCL at four dose levels ranging from 165 to $365 \mathrm{mg} / \mathrm{m}^{2} / \mathrm{dose}$

\begin{tabular}{llllllll}
\hline Dose level $\left(\mathrm{mg} / \mathrm{m}^{2} / \mathrm{dose}\right)$ & Number of subjects & $C_{\max }(\mathrm{ng} / \mathrm{mL})$ & $T_{\max }(\mathrm{h})$ & $\mathrm{AUC}_{0-\tau}(\mathrm{ng} \mathrm{h} / \mathrm{mL})$ & $C_{\mathrm{ave}}^{\mathrm{ss}}(\mathrm{ng} / \mathrm{mL})$ & $\mathrm{CL} / \mathrm{F}\left(\mathrm{mL} / \mathrm{min} / \mathrm{m}^{2}\right)$ & $C_{12 \mathrm{~h}}^{\mathrm{ss}}(\mathrm{ng} / \mathrm{mL})$ \\
\hline 165 & 1 & 294 & 6 & 2950 & 246 & 735 & 205 \\
215 & 5 & $601 \pm 118$ & $4.0 \pm 1.4$ & $5630 \pm 1370$ & $469 \pm 114$ & $652 \pm 159$ & $354 \pm 133$ \\
280 & 36 & $717 \pm 201$ & $3.8 \pm 1.7$ & $6990 \pm 2080$ & $582 \pm 173$ & $736 \pm 255$ & $480 \pm 176$ \\
365 & 7 & $972 \pm 210$ & $2.1 \pm 0.1$ & $8770 \pm 2740$ & $731 \pm 228$ & $731 \pm 223$ & $650 \pm 330$ \\
\hline
\end{tabular}

Values represent the mean $\pm \mathrm{SD}$

dose levels ranging from 100 to $365 \mathrm{mg} / \mathrm{m}^{2} /$ dose using four drug formulations. Crizotinib was dosed based on body surface area using a dosing nomogram. Despite differences in study design and sampling times, the pharmacokinetics of crizotinib in children appears to be similar to adults. The $\mathrm{CL} / \mathrm{F}$ of crizotinib in adults was $850 \mathrm{~mL} / \mathrm{min} / \mathrm{m}^{2}$ after a single fixed 250-mg dose in healthy volunteers and $600 \mathrm{~mL} /$ $\mathrm{min} / \mathrm{m}^{2}$ at steady state in adults with NSCLC $[8,9]$. These values are comparable to the mean $\mathrm{CL} / \mathrm{F}$ at steady state in children of $730 \mathrm{~mL} / \mathrm{min} / \mathrm{m}^{2}$. The $C_{\max }^{\mathrm{ss}}$ in adults with NSCLC and children is also comparable when adjusted for differences in the dose.

Blood sampling after a single oral 250-mg dose of crizotinib in healthy volunteers extended to $144 \mathrm{~h}$, which allows for an accurate determination of the $35 \mathrm{~h}$ terminal $T_{1 / 2}$ [8]. It is not feasible to withhold crizotinib dosing for $6 \mathrm{~d}$ to allow for extended blood sampling in children with cancer, and estimating the $T_{1 / 2}$ from the samples collected over $24 \mathrm{~h}$ yields a mean $T_{1 / 2}$ of $11 \mathrm{~h}$, which is an underestimation of the true $T_{1 / 2}$ rather than a true difference in the disposition of crizotinib in children versus adults. The $R$ calculated from the $\mathrm{C}_{12 \mathrm{~h}}$ after the first dose and the day 7 trough concentration in children was 4.9 , which is similar to 4.5 in adult [9], and the $T_{1 / 2}$ estimated from the mean $R$ in children was $36 \mathrm{~h}$, which is similar to the $T_{1 / 2}$ in adult healthy volunteers. Although this is an indirect method of estimating the $T_{1 / 2}$, it is likely to be more accurate than estimating it directly from the concentration-time curve after the first dose because of the limited sampling duration.

At the MTD $\left(280 \mathrm{mg} / \mathrm{m}^{2} /\right.$ dose $)$ of crizotinib in children, the mean $( \pm \mathrm{SD}) C_{\mathrm{ave}}^{\mathrm{ss}}$ is $580( \pm 170) \mathrm{ng} / \mathrm{mL}$, and the mean $C_{12 \mathrm{~h}}^{\mathrm{ss}}$ is $480( \pm 180) \mathrm{ng} / \mathrm{mL}$. Plasma protein binding of crizotinib in adults is 90\% [9], and free $C_{\mathrm{ave}}^{\mathrm{ss}}$ and $C_{12 \mathrm{~h}}^{\mathrm{ss}}$ are estimated to be 60 and $50 \mathrm{ng} / \mathrm{mL}$, respectively. These free drug concentrations exceed the $10 \mathrm{ng} / \mathrm{mL} \mathrm{IC} \mathrm{IC}_{50}$ of crizotinib in ALCL cell lines, Karpas299 and SU-DHL-1 that express the NPM-ALK fusion protein [10], consistent with the high objective response rate to crizotinib in children with ALCL treated on the phase $1 / 2$ trial even at doses below the MTD [6]. 

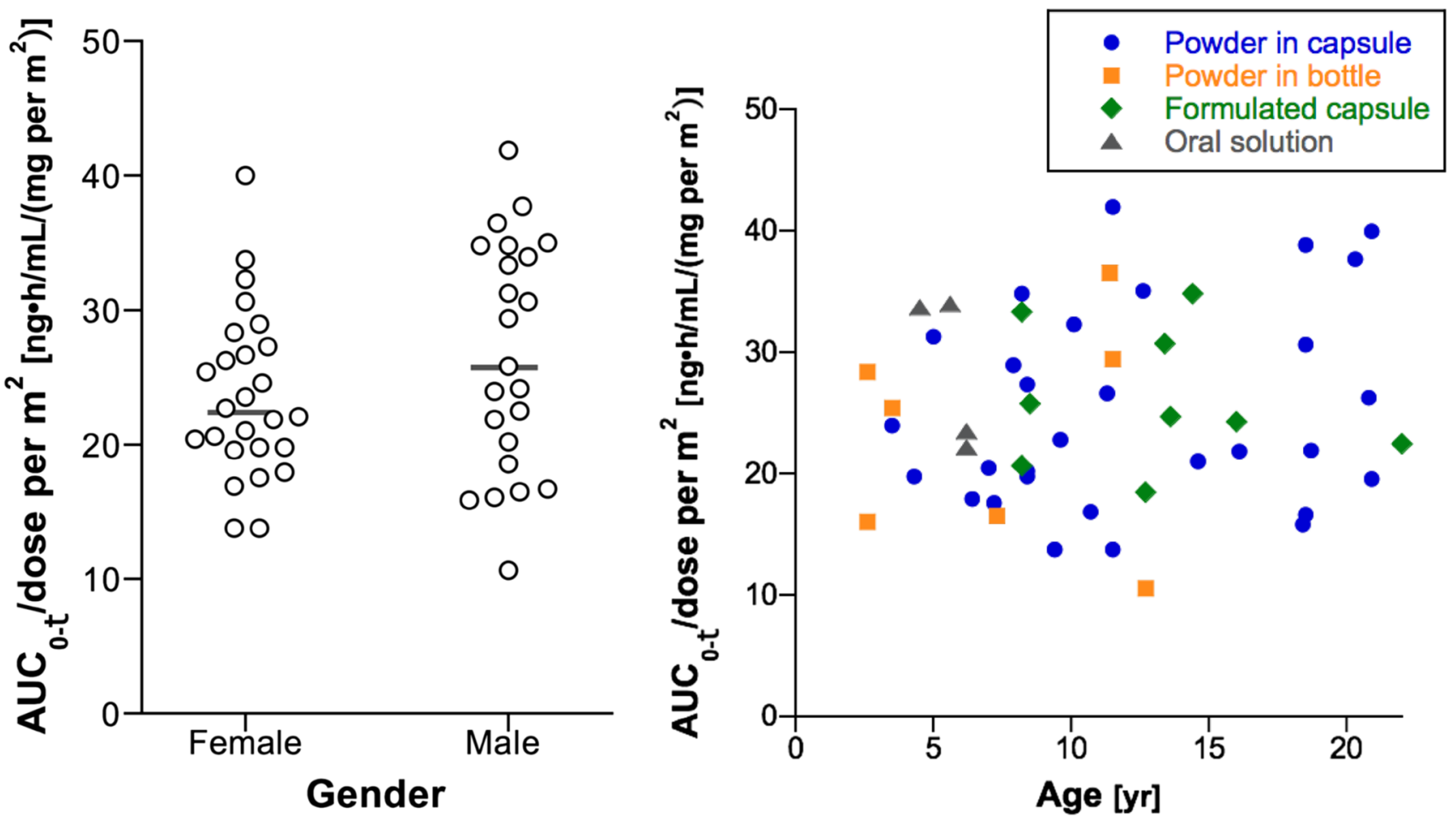

Fig. 3 Relationship of gender $(l e f t)$ and age by crizotinib formulation (right) to the $\mathrm{AUC}_{0-\tau}$ at steady state normalized to the administered dose per $\mathrm{m}^{2}$

The lactam metabolite of crizotinib, PF-06260182, is measurable in plasma, but at substantially lower concentrations than the parent drug [8]. Although PF-06260182 is active, it is considerably less potent than crizotinib, and it is not thought to contribute significantly to the in vivo activity of crizotinib $[9,11]$. For this reason, we did not monitor PF-06260182 plasma concentrations in children.

In summary, the pharmacokinetics of oral crizotinib in children is similar to that in adults. A more palatable formulation is currently being evaluated in children. Clinical trials of crizotinib alone and in combination with chemotherapy in children with neuroblastoma, other solid tumors and ALCL are ongoing.

Acknowledgements Pfizer provided crizotinib for the trial and Covance Indianapolis performed the crizotinib HPLC/MS/MS assay with funding from Pfizer. The Children's Oncology Group held the IND under which this trial was conducted.

Funding This clinical trial was supported by the National Cancer Institute (NCI) of the National Institutes of Health (NIH) [Award Number UM1 CA097452], Pfizer, Inc., Cookies for Kids' Cancer Foundation, Alex's Lemonade Stand Center of Excellence grant, and the Children's Oncology Group.

\section{Compliance with ethical standards}

Conflict of interest F. Balis has research funding from United Therapeutics Corp.; Y. Mosse has research funding from Pfizer, Inc. and Novartis; E. Fox has research funding from Glaxo Smith Kline, Merck and Incyta.

Ethical approval The phase 1 clinical trial of crizotinib was reviewed and approved by the Institutional Review Boards at each participating institution, and the clinical trial was conducted in accordance with the ethical standards outlined in the Declaration of Helsinki and the US Federal Regulations governing research in human subjects.

Open Access This article is distributed under the terms of the Creative Commons Attribution 4.0 International License (http://creativecommons.org/licenses/by/4.0/), which permits unrestricted use, distribution, and reproduction in any medium, provided you give appropriate credit to the original author(s) and the source, provide a link to the Creative Commons license, and indicate if changes were made.

\section{References}

1. Frampton JE (2013) Crizotinib: a review of its use in the treatment of anaplastic lymphoma kinase-positive, advanced 
non-small cell lung cancer. Drugs 73(18):2031-2051. doi:10.1007/s40265-013-0142-z

2. Cappuzzo F, Moro-Sibilot D, Gautschi O, Boleti E, Felip E, Groen HJ, Germonpre P, Meldgaard P, Arriola E, Steele N, Fox J, Schnell P, Engelsberg A, Wolf J (2015) Management of crizotinib therapy for ALK-rearranged non-small cell lung carcinoma: an expert consensus. Lung Cancer 87(2):89-95. doi:10.1016/j. lungcan.2014.12.010

3. Solomon BJ, Mok T, Kim DW, Wu YL, Nakagawa K, Mekhail T, Felip E, Cappuzzo F, Paolini J, Usari T, Iyer S, Reisman A, Wilner KD, Tursi J, Blackhall F (2014) First-line crizotinib versus chemotherapy in ALK-positive lung cancer. N Engl J Med 371(23):2167-2177. doi:10.1056/NEJMoa1408440

4. Camidge DR, Bang YJ, Kwak EL, Iafrate AJ, Varella-Garcia M, Fox SB, Riely GJ, Solomon B, Ou SH, Kim DW, Salgia R, Fidias P, Engelman JA, Gandhi L, Janne PA, Costa DB, Shapiro GI, Lorusso P, Ruffner K, Stephenson P, Tang Y, Wilner K, Clark JW, Shaw AT (2012) Activity and safety of crizotinib in patients with ALK-positive non-small-cell lung cancer: updated results from a phase 1 study. Lancet Oncol 13(10):1011-1019. doi:10.1016/S1470-2045(12)70344-3

5. Gambacorti-Passerini C, Messa C, Pogliani EM (2011) Crizotinib in anaplastic large-cell lymphoma. $\mathrm{N}$ Engl $\mathrm{J}$ Med 364(8):775-776. doi:10.1056/NEJMc1013224

6. Mosse YP, Lim MS, Voss SD, Wilner K, Ruffner K, Laliberte J, Rolland D, Balis FM, Maris JM, Weigel BJ, Ingle AM, Ahern C, Adamson PC, Blaney SM (2013) Safety and activity of crizotinib for paediatric patients with refractory solid tumours or anaplastic large-cell lymphoma: a Children's Oncology Group phase 1 consortium study. Lancet Oncol 14(6):472-480. doi:10.1016/ S1470-2045(13)70095-0

7. Murga-Zamalloa C, Lim MS (2014) ALK-driven tumors and targeted therapy: focus on crizotinib. Pharmacogenomics Pers Med 7:87-94. doi:10.2147/PGPM.S37504

8. Xu H, O'Gorman M, Boutros T, Brega N, Kantaridis C, Tan W, Bello A (2015) Evaluation of crizotinib absolute bioavailability, the bioequivalence of three oral formulations, and the effect of food on crizotinib pharmacokinetics in healthy subjects. J Clin Pharmacol 55(1):104-113. doi:10.1002/jcph.356

9. Hamilton G, Rath B, Burghuber O (2015) Pharmacokinetics of crizotinib in NSCLC patients. Expert Opin Drug Metab Toxicol 11(5):835-842. doi:10.1517/17425255.2015.1021685

10. Christensen JG, Zou HY, Arango ME, Li Q, Lee JH, McDonnell SR, Yamazaki S, Alton GR, Mroczkowski B, Los G (2007) Cytoreductive antitumor activity of PF-2341066, a novel inhibitor of anaplastic lymphoma kinase and c-Met, in experimental models of anaplastic large-cell lymphoma. Mol Cancer Ther 6(12 Pt 1):3314-3322. doi:10.1158/1535-7163.MCT-07-0365

11. Johnson TR, Tan W, Goulet L, Smith EB, Yamazaki S, Walker GS, O'Gorman MT, Bedarida G, Zou HY, Christensen JG, Nguyen LN, Shen Z, Dalvie D, Bello A, Smith BJ (2015) Metabolism, excretion and pharmacokinetics of [14C]crizotinib following oral administration to healthy subjects. Xenobiotica 45(1):45-59. doi:10.3109/00498254.2014.941964 